\title{
Cultivation and Improvement of College Teachers' Informatization Teaching Ability in the Era of Education Informatization 2.0
}

Lihua Gong

Teaching Quality Control Center of Taishan University

Abstract: The advent of the informatization 2.0 era has brought greater vitality and vitality to the reform work in the field of education in my country. In order to achieve a more long-term development of higher education, high-efficiency teachers need to actively break through the restraint of the old education model and follow the development trend of the information age to improve their information teaching ability in order to ensure the orderly progress of teaching activities. New talents that meet the needs of society. This article starts with the specific elements of informationbased teaching ability, and looks for specific ways to improve teaching ability, hoping to provide a reference for other educators.

Keywords: Information age; higher education; ability improvement; teaching ability

\begin{abstract}
Teachers, as important guides and companions for students to participate in learning activities, not only shoulder the important task of imparting their knowledge, but also need to play a positive role in promoting the improvement of students' ideological and moral levels, values, thinking consciousness and comprehensive literacy. The advent of education informatization 2.0 requires higher teachers' informatization ability. Under the constant changes of the times, how to make one's own teaching level and ability meet the requirements of educational development has become a problem that needs to be studied by teachers in colleges and universities. Therefore, teachers need to break through the constraints of old ideas and actively improve their teaching perspectives and teaching methods in order to promote the rapid rise of their teaching experience and professional level in the process of looking for ways to improve information teaching ability, and then achieve the promotion of higher education The purpose of flourishing.
\end{abstract}

\section{The specific components of the informatization teaching ability}

\subsection{Teaching ability}

Teaching ability, as a teacher's necessary teaching quality, can directly affect the teaching design, classroom teaching, and teaching effectiveness. Educational work is a practical activity that is different from the general social communication standards. The introduction of information technology can not only enable teachers to break through the constraints of outdated teaching concepts. When introducing information technology into teaching activities, it can also analyze the actual teaching situation and use information Technology is introduced into all aspects of teaching activities, so that teachers' teaching ability can be effectively improved while ensuring the effective development of classroom teaching activities.

\subsection{Development Ability}

As an important component of informatization teaching ability, development ability requires teachers to continue to increase their own knowledge reserves and enhance informatization development ability in order to keep improving their teaching level and teaching ability in the process of keeping up with the development of the times the goal of. Due to the rapid innovation of information technology, if teachers do not have the corresponding development capabilities,

Copyright (C) 2020 Lihua Gong

doi: 10.18282/le.v9i5.1223

This is an open-access article distributed under the terms of the Creative Commons Attribution Non-Commercial License

(http://creativecommons.org/licenses/by-nc/4.0/), which permits unrestricted non-commercial use, distribution, and reproduction in any medium, provided the original work is properly cited. 
they will not only lag behind the wave of development of the times, but also make it difficult to effectively introduce information technology into classroom teaching activities and fail to exert their applied educational effectiveness.

\subsection{Communication skills}

The introduction of information technology can effectively use the Internet platform to expand communication channels, so that teachers and students can communicate more timely in classroom teaching activities or online online learning. Therefore, teachers not only master the students' learning direction and the overall learning situation, but also can improve the teaching content according to the actual needs. This not only can effectively mobilize students' learning initiative, but also promote the establishment of high-quality classroom teaching activities in the process of improving teachers' information teaching ability.

\section{The specific ways to improve the informatization teaching ability of college teachers in the background of education informatization 2.0}

\subsection{Establish an informatization teacher team}

In order to implement the requirements of teachers' teaching ability, professional literacy and teaching level in the era of education informatization 2.0, colleges and universities need to actively establish their own informatization teacher team in order to promote the rapid scientific research level of the school while improving their teaching ability rise.

On the one hand, the school needs to define the direction of informatization talent cultivation, actively carry out training activities that meet the needs of teacher development, and implement informatization literacy into it. Through the participation of training activities, teachers can not only learn more emerging educational concepts, but also ensure the rapid rise of their teaching experience and teaching ability in the process of continuously improving their information literacy.

On the other hand, schools need to improve the assessment mechanism and improve the current teaching ability assessment standards. Through the addition of information literacy, teachers should pay more attention to improving their teaching ability. And a more stimulating assessment system can not only arouse the enthusiasm of teachers for continuous learning, but also in the process of seeking to train their teaching ability, so that they can grow into highquality teachers that meet the requirements of the information age.

\subsection{Improve the skills of teachers in applying information technology}

Informatization teaching methods are diverse, so when teachers carry out informatization teaching activities, only with a high application ability can they effectively introduce various informatization teaching tools into the classroom. The era of education informatization 2.0 has enabled different industries to develop rapidly under the constantly changing market economy. In order to cultivate highly skilled talents that meet the requirements of social development, teachers need to apply information technology to the future development trends of various majors. Integrate and predict, and use big data to develop educational resources in a deeper way, so that students can learn their classroom knowledge and improve their industry perception, so as to formulate future development directions in a more directional manner. In addition, teachers can not only extend the teaching content through the application of information technology during the teaching work, but also a variety of classroom expressions are more likely to attract students to participate in enthusiasm, so that while ensuring the effectiveness of classroom teaching, it is easier for teachers to exercise their teaching ability, And then continue to improve their information literacy while ensuring the high-quality completion of teaching work.

\section{Conclusion}

The advent of the information age has ushered in tremendous reforms in different industries, and made the development of our education system more complete. Therefore, under the background of educational informatization 2.0, how to enable teachers to adapt to the development wave of the times and effectively improve their teaching ability, teaching level and teaching experience has become a problem that needs to be solved by teachers in colleges 
and universities. This requires teachers to grasp the development of the times, deeply realize the positive significance of the instructive ability of informatization, and in combination with the actual teaching situation, continue to find ways to improve in order to promote high-level in the process of building high-quality informatized classroom teaching activities The long-term development of informatization education in colleges and universities.

\section{References}

1. Ye Ling, Gao Rong. Investigation and Research on the Status of Informatization Teaching of English Teachers in Local Universities under the Background of "Internet $+"$ —_ Taking Hubei $\times \times$ College as an Example[J]. Education Modernization, 2019, 6(64): 232 -233.

2. Zhang Yang, Hong Bin. Exploration and Practice of the Collaborative Development Model of "Integrated Six Wings" Informatized Teaching in Universities_— Taking Hunan Agricultural University as an Example[J]. Journal of Hebei Agricultural University (Social Science Edition), 2019, 21(01 ): 46-51.

3. Ji Xiaoli, Wang Yan, Fang Xiaoyong, Gong Jian. Status and development countermeasures of informatization teaching ability of college English teachers_—Based on a survey of 76 colleges and universities in Jiangsu Province[J]. Informatization of Education in China, 2018(24):72- 76. 